Research article Open Access

\title{
Targeted therapy against Bcl-2-related proteins in breast cancer cells
}

\author{
Manabu Emi ${ }^{1}$, Ryungsa Kim², Kazuaki Tanabe ${ }^{1}$, Yoko Uchida ${ }^{1}$ and Tetsuya Toge ${ }^{1}$
}

\author{
1Department of Surgical Oncology, Research Institute for Radiation Biology and Medicine, Hiroshima University, Hiroshima, Japan \\ 2International Radiation Information Center, Research Institute for Radiation Biology and Medicine, Hiroshima University, Hiroshima, Japan \\ Corresponding author: Ryungsa Kim, rkim@hiroshima-u.ac.jp
}

Received: 2 Feb 2005 Revisions requested: 3 Mar 2005 Revisions received: 25 Aug 2005 Accepted: 31 Aug 2005 Published: 28 Sep 2005

Breast Cancer Research 2005, 7:R940-R952 (DOI 10.1186/bcr1323)

This article is online at: http://breast-cancer-research.com/content/7/6/R940

(C) 2005 Emi et al.; licensee BioMed Central Ltd.

This is an Open Access article distributed under the terms of the Creative Commons Attribution License (http://creativecommons.org/licenses/by/ 2.0), which permits unrestricted use, distribution, and reproduction in any medium, provided the original work is properly cited.

\begin{abstract}
Introduction Bcl-2 and $\mathrm{Bcl}-\mathrm{xL}$ confer resistance to apoptosis, thereby reducing the effectiveness of chemotherapy. We examined the relationship between the expression of Bcl-2 and $\mathrm{Bcl}-\mathrm{xL}$ and chemosensitivity of breast cancer cells, with the aim of developing specific targeted therapy.

Methods Four human breast cancer cell lines were examined, and the effects of antisense (AS) $B c /-2$ and AS Bcl-xL phosphorothioate oligodeoxynucleotides (ODNs) on chemosensitivity were tested in vitro and in vivo. Chemosensitivity was evaluated by the MTT (3- $(4,5-$ dimethylthiazol-2-yl)-2,5-diphenyl-2H-tetrazolium bromide) assay, and the antitumor effect was assessed in vivo by the success of xenograft transplantation into athymic mice.
\end{abstract}

Results Treatment with AS Bcl-2 and $B c /-x L$ ODNs resulted in a sequence-specific decrease in protein expression, compared with controls. Treatment of BT-474, ZR-75-1, and MDA-MB231 cells with AS $\mathrm{Bcl}-2$ increased chemosensitivity to doxorubicin (DOX), mitomycin C (MMC), paclitaxel (TXL), and docetaxel (TXT). Transfection of the $\mathrm{Bcl}-2$ gene into MDA-MB453 cells decreased sensitivity to DOX and MMC. Treatment of MDA-MB-231, BT-474, and ZR-75-1 cells with AS Bcl-xL increased chemosensitivity to DOX, MMC and taxanes to a smaller extent than AS Bcl-2. This occurred in the setting of increased Bax and cleaved poly(ADP-ribose) polymerase, as well as decreased $\mathrm{Bcl}-2$ and pAkt. AS Bcl-2 ODNs induced splenomegaly in association with increased serum IL-12, which was attenuated by methylation of the $\mathrm{CpG}$ motifs of AS Bcl-2; however, methylated $\mathrm{CpG}$ failed to negate the increased antitumor effect of $\mathrm{AS} \mathrm{Bcl-2.} \mathrm{Bcl-2} \mathrm{and} \mathrm{Bcl}-\mathrm{xL}$, to a smaller extent, are major determinants of chemosensitivity in breast cancer cells.

Conclusion Targeted therapy against Bcl-2 protein with the use of AS ODNs might enhance the effects of chemotherapy in patients with breast cancer.

\section{Introduction}

$\mathrm{Bcl}-2$ and $\mathrm{Bcl}-\mathrm{xL}$ proteins are inhibitors of the mitochondrial apoptosis pathway; they exert their action by blocking their proapoptotic counterparts, including Bid and Bax, thereby preventing the release of cytochrome $c$ and the activation of caspase $[1,2]$. Bcl-xL shows remarkable homology to Bcl-2 and inhibits apoptosis as effectively as Bcl-2 in some cells. Furthermore, $\mathrm{Bcl}-\mathrm{xL}$ is capable of preventing cell death when Bcl-2 fails to do so, suggesting that these proteins exert independent effects on the mitochondrial apoptotic pathway [3]. Given that $\mathrm{Bcl}-2$ and $\mathrm{Bcl}-\mathrm{xL}$ are capable of inhibiting antican- cer drug-induced apoptosis, which is mediated by the voltagedependent anion channel (VDAC) in the outer mitochondrial membrane, overexpression of $\mathrm{Bcl}-2$ and $\mathrm{Bcl}-\mathrm{xL}$ might confer resistance to chemotherapy [4]. In fact, overexpression of Bcl2 and $\mathrm{Bcl}-\mathrm{xL}$ is observed in several cancers, including hematologic malignancies, as well as a range of solid tumors, including nasopharyngeal, colorectal, prostate, and breast cancer [5-7].

Antisense oligodeoxynucleotides (AS ODNs) are short, synthetic stretches of DNA that hybridize with specific mRNA

ANOVA $=$ analysis of variance; $\mathrm{AS}=$ antisense; $\mathrm{CREB}=$ cyclic-AMP-responsive element-binding protein; $\mathrm{DMSO}=$ dimethyl sulfoxide; $\mathrm{DOX}=$ doxorubicin; $E R=$ estrogen receptor; IL = interleukin; $L S D=$ least significant difference; $M M=$ mismatch control; MTT = 3-(4,5-dimethylthiazol-2-yl)-2,5diphenyl-2H-tetrazolium bromide; ODN = oligodeoxynucleotide; $\mathrm{PARP}=$ poly(ADP-ribose) polymerase; $\mathrm{RC}=$ random control; TXL $=$ paclitaxel; TXT $=$ docetaxel; VDAC $=$ voltage-dependent anion channel. 
strands corresponding to target genes. By binding to mRNA, AS ODNs prevent the translation of target proteins, thereby blocking gene expression. Phosphorothioate ODNs, in which the oxygen atom of the phosphodiester moiety of the DNA backbone is replaced by sulphur, are the most commonly used first-generation AS ODNs because they have acceptable physical and chemical properties while showing resistance to nucleases [8]. Several studies indicate that overexpression of $\mathrm{Bcl}-2$ inhibits apoptosis induced by anticancer drugs, radiation, and other DNA-damaging agents $[9,10]$. In addition, increased sensitivity to anticancer drugs after treatment with AS Bcl-2 is observed in solid tumors, such as breast, prostate, lung, and gastric cancer [11-14]. Similarly, downregulation of $\mathrm{Bcl}-\mathrm{xL}$ protein expression by AS ODNs in various tumor cell lines resulted in activation of apoptosis, as well as decreased cellular proliferation and increased sensitivity to cytotoxic chemotherapeutic agents $[15,16]$.

The two CpG motifs of AS Bcl-2, which are unmethylated dinucleotide sequences of cytosine followed by guanine, are associated with potent immune stimulation [17]. CpG ODNs administered in the vicinity of various animal tumors show marked antitumor activity $[18,19]$. However, it remains unclear whether immune stimulation is responsible for the antitumor effects of AS Bcl-2 ODNs.

In the present study we examined the effects of downregulation of $\mathrm{Bcl}-2$ and $\mathrm{Bcl}-\mathrm{xL}$ on the chemosensitivity of breast cancer cells in vitro and in vivo with the aim of using this approach as a specific targeting therapy. The possibility of using growth inhibition as a mechanism by which AS Bcl-2 ODNs enhance chemosensitivity was also explored. Furthermore, we studied the effect of $B c /-2$ gene transfection on the chemosensitivity of a breast cancer cell line that normally expresses a low basal level of Bcl-2. Finally, we attempted to evaluate the effects of the two AS Bcl-2 CpG motifs on immunostimulatory function and antitumor activity in athymic mice.

\section{Materials and methods Materials}

The human breast cancer cell lines BT-474, ZR-75-1, MDAMB-231, and MDA-MB-453 were obtained from the American Type Culture Collection (Manassas, VA, USA). Cells were cultured in RPMI-1640 (Gibco BRL, New York, USA) containing $10 \%$ heat-inactivated fetal bovine serum and antibiotics. Cultures were maintained in a humidified incubator at $5 \% \mathrm{CO}_{2}$ and $37^{\circ} \mathrm{C}$.

\section{ODNs and anticancer drugs}

Phosphorothioate ODNs, purified by reverse-phase high-performance liquid chromatography, were purchased from Biologica (Tokyo, Japan). The following AS Bcl-2 oligonucleotide sequence, corresponding to the first six codons of the human Bcl-2 open reading frame, was used: AS 5'-TCTCCCAGCGTGCGCCAT-3' [20]. The following Bcl-2 oligonu- cleotide sequences were used as controls: 5'TCTCCCAGCATGTGCCAT-3' as a two-base mismatch control (MM), and 5'-TACCGCGTGCGACCCTCT-3' as a random control (RC). Phosphorothioate oligonucleotides corresponding to the initiation site of human $\mathrm{Bcl}-2$ described above were made with 5 '-methylation of cytosine $(\mathrm{m} 5 \mathrm{C})$ residues in the two $\mathrm{CpG}$ motifs: 5'TCTCCCAG ${ }^{5}{ }^{C G T G}{ }^{5}{ }^{5}$ CGCCAT-3'. The following $B c l-x L^{2}$ target sequence was used: 5'-CCATCCCGGAAGAGTTCATT- 3 '. In addition, the following $B c l-x L$ sequences were used as a sense control and a two-base MM: 5'-AATGAACTCTTCCGGGATGG-3' [16] and 5'-CCATCCCAGAAGAGTTTATT-3', respectively. The $B c l-2$ and $B c l-x L$ sequences were not homologous with $B c l-x S$ or with any other known human gene sequences. All of the oligonucleotides were diluted to a concentration of $1 \mathrm{mM}$, filter-sterilized, and stored at $-30^{\circ} \mathrm{C}$ in distilled water. Doxorubicin (DOX) and mitomycin C (MMC) were from Kyowa Hakko Co., Ltd (Tokyo, Japan), paclitaxel (TXL) was from Bristol-Myers K.K. (Tokyo, Japan), and docetaxel (TXT) was from Aventis Pharma (Tokyo, Japan). DOX, MMC, and TXT were prepared with saline solution, and TXL was dissolved in dimethyl sulfoxide (DMSO).

\section{Cell extraction and Western blotting}

Cells were washed twice with PBS, centrifuged at $2,700 \mathrm{~g}$ and $4^{\circ} \mathrm{C}$, and lysed with lysis buffer containing $10 \mathrm{mM}$ Tris$\mathrm{HCl} \mathrm{pH} \mathrm{8.0,} \mathrm{0.15} \mathrm{M} \mathrm{NaCl,} 1$ mM EDTA, 10 mM CHAPS, 10 $\mu \mathrm{g} / \mathrm{ml}$ aprotinin, and $0.02 \mathrm{mM}$ phenylmethylsulfonyl fluoride. Lysate was incubated for $15 \mathrm{~min}$ on ice and centrifuged for 15 min at 2,700 g. Supernatant was collected and the protein quantity was estimated with Bio-Rad protein assay dye (BioRad, Hercules, CA, USA). Samples containing equal amounts of protein $(15 \mu \mathrm{g})$ were subjected to electrophoresis on a $12.5 \%$ sodium dodecyl sulfate-polyacrylamide gel, and transferred to a poly(vinylidene difluoride) membrane. After being blocked overnight with PBS containing 5\% nonfat milk powder, the membrane was incubated with primary antibody (1:200 dilution) for 1 hour at room temperature at $25^{\circ} \mathrm{C}$. Antibodies used for specific immune blotting included anti-Bcl-2, anti-Bcl-xL, anti-Bax, anti-pAkt, anti-poly(ADP-ribose) polymerase (anti-PARP), and anti- $\beta$-actin. All antibodies were obtained from Santa Cruz Biotechnology (Santa Cruz, CA, USA). The membrane was washed three times with PBS and then incubated with anti-rabbit or anti-mouse IgG antibody $(1: 1,000$ dilution; Sigma Chemical, St Louis, MO, USA) for 1 hour at room temperature. After three washes with PBS, specific protein bands were detected with an enhanced chemiluminescence western blot detection system (ECL; Amersham Pharmacia Biotech, Little Chalfont, Bucks, UK), and detected after exposure to Hyper film ECL (Amersham Pharmacia Biotech, Little Chalfont, Bucks, UK). Each protein signal was quantified with Scion image software (Scion Corporation, Frederick, MA, USA). 
Figure 1

(a)

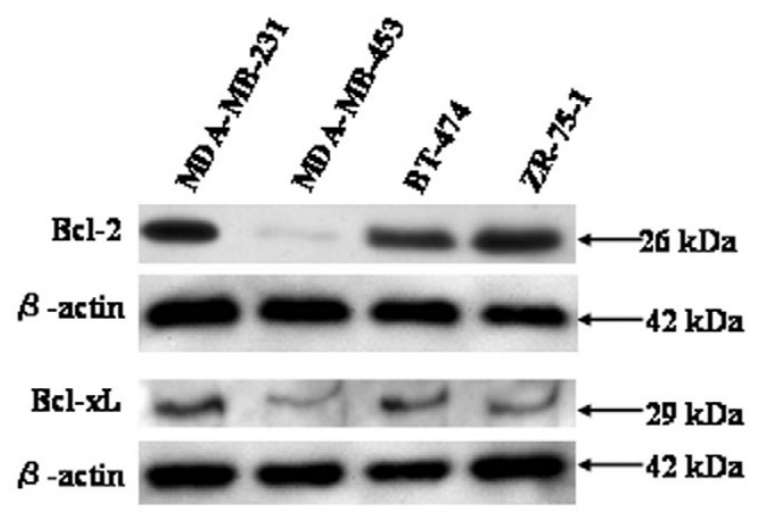

(b)

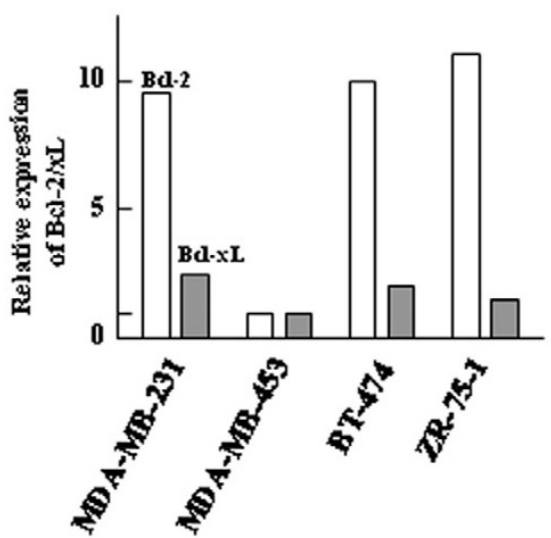

Expression levels of $\mathrm{Bcl}-2$ and $\mathrm{Bcl}-\mathrm{xL}$ proteins in MDA-MB-231, MDAMD-453, BT-474, and ZR-75-1 cells. (a) Western blot analysis of Bcl-2 and $\mathrm{Bcl}-\mathrm{xL}$ expression. (b) Quantification of $\mathrm{Bcl}-2$ and $\mathrm{Bcl}-\mathrm{xL}$ expression by densitometric analysis. The relative expression of $\mathrm{Bcl}-2$ and $\mathrm{Bcl}-$ $x \mathrm{~L}$ in MDA-MB-453 cells was compared with the expression in MDAMB-231, BT-474, and ZR-75-1 cells. Results are from two representative, independent experiments.

\section{MTT assays and cell viability}

Cells were seeded into 96 -well plates at $10^{4}$ viable cells per well and left to attach to the plate for 24 hours. After 24 hours, cells were treated with anticancer drugs for 48 hours. The final volume was $200 \mu \mathrm{l}$ per well. Subsequently, $200 \mu \mathrm{l}$ of medium containing $0.25 \mathrm{mg} / \mathrm{ml}$ 3-(4,5-dimethylthiazol-2-yl)-2,5-diphenyl-2H-tetrazolium bromide (MTT; Sigma Chemical, Tokyo, Japan) was added to each well for 3 hours. The medium was then removed and $150 \mu \mathrm{l}$ of DMSO (Wako Pure Chemical Industries, Osaka, Japan) was added to each well for $30 \mathrm{~min}$ at room temperature. The absorbance of each well was measured with a microculture plate reader at $540 \mathrm{~nm}$. Growth inhibition was expressed as a ratio of the mean absorbance of drug-treated cells to that of control cells. Experiments were performed in triplicate, and growth inhibition rates and $I_{50}$ values were calculated. Cell viability was also assessed with the trypan blue dye-exclusion test.
Figure 2

(a)

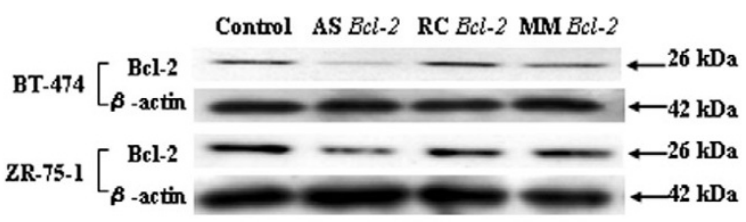

(b)

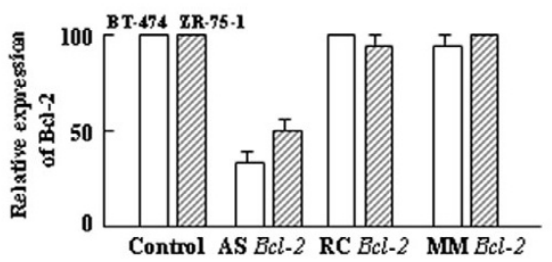

(c)

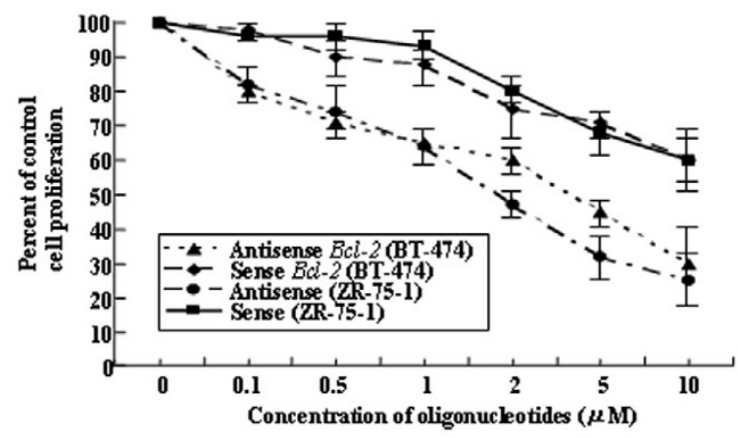

Sequence-specific downregulation and cytotoxic effects of antisense Bcl-2 oligodeoxynucleotides on BT-474 and ZR-75-1 cells. (a) Specific inhibition of $\mathrm{Bcl}-2$ protein expression by treatment with antisense (AS) Bcl-2 oligodeoxynucleotides (ODNs). Cells were treated with 10 $\mu \mathrm{g} / \mathrm{ml}$ Lipofectamine alone (control) or $1.0 \mu \mathrm{M} \mathrm{AS}$, mismatch control (MM), or random control (RC) ODNs for 24 hours. Cells were then cultured in standard medium, total protein was extracted, and Bcl-2 and $\beta$ actin protein levels were analyzed by Western blotting. (b) Quantification of $\mathrm{Bcl}-2$ expression by densitometric analysis. The expression of $\mathrm{Bcl}-2$ in cells treated with control, AS Bcl-2, RC Bcl-2, and MM Bcl-2 ODNs was normalized with $\beta$-actin, and the relative values are presented. Error bars indicate SD. The data presented are from three independent experiments. (c) Effects of AS Bcl-2 ODNs on the proliferation of BT-474 and ZR-75-1 breast cancer cells in vitro. Cells were treated with various concentrations of AS Bcl-2 ODNs in 24-well dishes. Four days after treatment, cells were stained with trypan blue and counted. Error bars indicate SD. The data presented are from three independent experiments.

\section{Transfection}

pZip ${ }_{\text {neo }}$ plasmid expression vectors containing human $b c /-2$ cDNA were used [21]. MDA-MB-453 cells in the exponential phase of growth were transfected with the $\mathrm{pZip}_{\text {neo }}$ plasmid expression vector with the use of Lipofectamine 2000 (Invitrogen Corp., Carlsbad, CA, USA), in accordance with the instructions provided by the manufacturer. After this, cells were selected with $400 \mu \mathrm{g} / \mathrm{ml}$ Geneticin Liquid (Gibco BRL, New York, USA), and the resulting clones were pooled. The 
Table 1

Effect of antisense Bcl-2 oligodeoxynucleotides on chemosensitivity in BT-474, ZR-75-1, and MDA-MB-231 breast cancer cells

\begin{tabular}{|c|c|c|c|c|c|}
\hline \multirow[t]{2}{*}{ Cell line } & \multirow[t]{2}{*}{ Drug } & \multicolumn{3}{|c|}{$\mathrm{IC}_{50}(\mu \mathrm{M})^{\mathrm{a}}$} & \multirow[t]{2}{*}{ Fold increase in AS Bcl-2 } \\
\hline & & Control & Sense $B c /-2^{b}$ & AS Bcl-2b & \\
\hline \multirow[t]{5}{*}{ BT-474 } & AS $B c /-2$ & 3.6 & -- & -- & -- \\
\hline & DOX & 1.0 & 0.97 & 0.12 & 8.3 \\
\hline & MMC & 1.4 & 1.3 & 0.81 & 1.7 \\
\hline & TXL & 2.4 & 2.3 & 0.29 & 8.3 \\
\hline & TXT & 0.54 & 0.50 & 0.054 & 10.0 \\
\hline \multirow[t]{5}{*}{ ZR-75-1 } & AS $B c /-2$ & 1.8 & -- & -- & -- \\
\hline & DOX & 0.54 & 0.48 & 0.075 & 7.2 \\
\hline & MMC & 0.84 & 0.77 & 0.33 & 2.5 \\
\hline & TXL & 1.9 & 1.7 & 0.62 & 3.1 \\
\hline & TXT & 3.1 & 2.8 & 0.80 & 3.9 \\
\hline \multirow[t]{5}{*}{ MDA-MB-231 } & AS $B c /-2$ & 5.2 & -- & -- & -- \\
\hline & DOX & 0.19 & 0.17 & 0.032 & 5.9 \\
\hline & MMC & 0.68 & 0.62 & 0.22 & 3.1 \\
\hline & TXL & 2.8 & 2.6 & 0.43 & 6.5 \\
\hline & TXT & 1.2 & 1.1 & 0.23 & 5.2 \\
\hline
\end{tabular}

AS, antisense; DOX, doxorubicin; $\mathrm{IC}_{50}$, concentration for 50\% inhibition; MMC, mitomycin C; TXL, paclitaxel; TXT, docetaxel.

aThe data are the means of three separate experiments $(\mathrm{SD}<5 \%)$; bcells were treated with $1 \mu \mathrm{M}$ sense $B c l-2$ or antisense $B c /-2$.

expression of Bcl-2 by MDA-MB-453 cells was determined by Western blotting with a monoclonal antibody against Bcl-2.

\section{Antitumor activity in vivo}

Four-week-old female athymic mice (Balb/c, nu/nu) were obtained from Clea Japan (Tokyo, Japan). The research protocol was in accordance with the institutional guidelines of the Hiroshima University Animal Care and Use Committee. BT474 (estrogen receptor (ER)-positive), ZR-75-1 (ER-positive), and MDA-MB-231 (ER-negative), cells were established as subcutaneous xenografts by the injection of $10^{7}$ cells suspended in $150 \mu \mathrm{l}$ of Matrigel (Becton Dickinson Labware, Bedford, MA, USA) in the lateral back region.

Mice were implanted subcutaneously with pellets engineered to give a controlled release of $0.72 \mathrm{mg}$ of $17 \beta$-estradiol over 60 days (Innovative Research, Sarasota, FL, USA) 1 week before estrogen-dependent cell implantation. When palpable tumors arose, three or four pieces ( 1 to $2 \mathrm{~mm}^{3}$ ) of nonnecrotic tissue were subcutaneously transplanted into other mice with the use of a biomedical stainless steel needle (implant needle) under anesthesia. Once tumors had reached a volume of about $100 \mathrm{~mm}^{3}$, mice were randomized to receive one of the following treatments: no treatment (control group); treatment with AS Bcl-2 or AS Bcl- $x$ L ODNs; treatment with various anticancer agents; or combined treatment with AS ODNs and various anticancer agents. AS Bcl-2 and AS Bcl- $x$ L ODNs (5 mg/ $\mathrm{kg}$ ) were administered by intraperitoneal injection 6 days a week, every other week for 4 weeks. The anticancer agents were administered once a week for 4 weeks as $10 \mathrm{mg} / \mathrm{kg} \mathrm{TXL}$ or TXT, or $2 \mathrm{mg} / \mathrm{kg} \mathrm{MMC}$, by intraperitoneal injection, or $6 \mathrm{mg} /$ $\mathrm{kg}$ doxorubicin by bolus injection into the tail vein. Serial measurements of tumor diameter were made with calipers, and tumor volumes were calculated as volume $=$ width $^{2} \times$ length $/ 2$.

\section{Serum levels of IL-12}

Changes in serum levels of IL-12 after exposure to AS Bcl-2 ODNs, as well as AS Bcl-2 ODNs with methylated $\mathrm{CpG}$ motifs (synthetic CpG AS Bcl-2 ODNs), were measured by enzyme-linked immunosorbent assay (SRL, Tokyo, Japan); the results were compared with control values. Changes in splenic weight and serum IL-12 levels were evaluated after treatment with AS Bcl-2 or synthetic CpG AS Bcl-2 ODNs.

\section{Statistical analysis}

All of the linear regression was performed with Microsoft Excel (Seattle, WA, USA). Student's $t$-test was used to measure statistical significance between two treatment groups. Multiple 
comparisons were performed with a one-way analysis of variance (ANOVA). Data were considered significant if $P<0.05$.

\section{Results}

Expression of $\mathrm{Bcl}-2$ and $\mathrm{Bcl}-\mathrm{xL}$ in breast cancer cell lines To assess the expression of $\mathrm{Bcl}-2$ and $\mathrm{Bcl}-\mathrm{xL}$ in breast cancer cell lines, western blot analysis was performed (Fig. 1). Bcl-2 and $\mathrm{Bcl}-\mathrm{xL}$ proteins were expressed in MDA-MB-231, BT-474, and ZR-75-1 cells, whereas Bcl-2 and Bcl-xL expression in MDA-MB-453 cells was observed to a smaller extent. These findings suggest differential regulation in the expression of $\mathrm{Bcl}-2$ and $\mathrm{Bcl}-\mathrm{xL}$ protein in breast cancer cells.

\section{Sequence-specific downregulation and cytotoxic effects of AS BCl-2}

We examined the effect of AS oligonucleotide treatment on $\mathrm{Bcl}-2$ protein expression. Western blot analysis showed that BT-474 and ZR-75-1 cells transfected with $1.0 \mu \mathrm{M}$ AS Bcl-2 oligonucleotides produced significantly less $\mathrm{Bcl}-2$ protein than cells treated with RC and MM oligonucleotides, or with Lipofectamine alone. Bcl-2 protein expression was decreased by $70 \%$ and $50 \%$, compared with control values, in BT-474 and ZR-75-1 cells, respectively (Fig. 2a,b). Also, as shown in Fig. 2c, treatment of BT-474 and ZR-75-1 cells with AS Bcl-2 oligonucleotides inhibited cell proliferation in a dose-dependent manner. In contrast, control sense oligonucleotides had a minimal effect on cell growth at concentrations up to $1.0 \mu \mathrm{M}$. Greater concentrations of control sense oligonucleotides had cytotoxic effects. A dose-response effect with regard to downregulation of $\mathrm{Bcl}-2$ protein expression was observed in ZR-75-1 and BT-474 cells, resulting in maximal inhibition approaching $50 \%$ and $70 \%$, respectively, at concentrations up to $2.0 \mu \mathrm{M}$. However, the maximum inhibition of $70 \%$ for Bcl2 protein was also observed at $1.0 \mu \mathrm{M}$ AS Bcl-2 ODNs, which was the optimal dose for limiting cytotoxicity in the MDA-MB231 cell line (data not shown).

\section{Effect of AS Bcl-2 on chemosensitivity}

To evaluate whether treatment of BT-474, ZR-75-1, and MDAMB-231 cells with AS Bcl-2 in combination with anticancer drugs enhances antitumor effects in vitro, we used the MTT assay to examine the efficacy of DOX, MMC, TXL, and TXT in the presence and absence of AS Bcl-2. BT-474, ZR-75-1, and MDA-MB-231 cells were treated with $1.0 \mu \mathrm{M}$ sense $\mathrm{Bcl}-2$ or AS Bcl-2, or Lipofectamine alone, for 24 hours, and then incubated with various concentrations of anticancer drugs for a further 48 hours. MTT assays were then performed to determine cell viability. As shown in Table 1, although treatment with sense Bcl-2 affected the chemosensitivity somewhat, treatment of BT-474 cells with AS Bcl-2 resulted in 8.3-fold, 8.3fold, and 10.0-fold increases in sensitivity to DOX, TXL, and TXT, respectively. In contrast, treatment with $\mathrm{AS} \mathrm{Bcl}-2$ and MMC did not enhance the drug sensitivity of BT-474 cells to the same extent. Treatment of ZR-75-1 cells with AS Bcl-2 resulted in 7.2-fold, 2.5-fold, 3.1-fold and 3.9-fold increases in
Figure 3

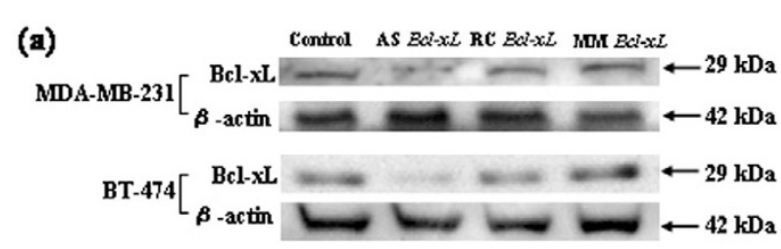

(b)

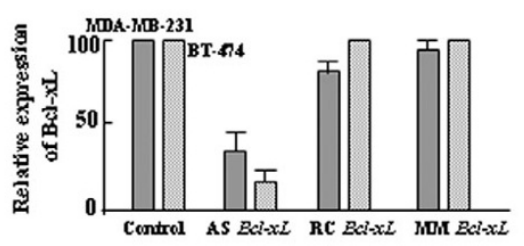

(c)

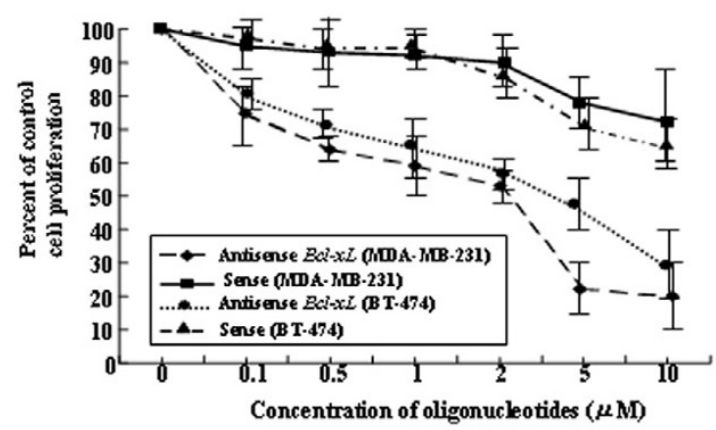

Sequence-specific downregulation and cytotoxic effects of antisense $B c l-x L$ oligodeoxynucleotides on MDA-MB-231 and BT-474 cells. (a) Specific inhibition of Bcl-xL protein expression by treatment with antisense (AS) $B c l-x L$ oligodeoxynucleotides (ODNs). Cells were treated with $10 \mu \mathrm{g} / \mathrm{ml}$ Lipofectamine alone (control) or $1.0 \mu \mathrm{M} \mathrm{AS}$, mismatch control (MM), or random control (RC) ODNs for 24 hours. Cells were then cultured in standard medium, total protein was extracted, and Bcl$\mathrm{xL}$ and $\beta$-actin protein levels were analyzed by Western blotting. (b) Quantification of $\mathrm{Bcl}-\mathrm{xL}$ protein expression by densitometric analysis. The Bcl-xL protein expression was normalized with $\beta$-actin, and the relative values are presented. Error bars indicate SD. The data presented are from three independent experiments. (c) Effects of AS Bcl-xL ODNs on the proliferation of MDA-MB-231 and BT-474 breast cancer cells in vitro. Cells were treated with various concentrations of $\mathrm{AS} \mathrm{Bcl-}$ $x L$ ODNs in 24-well dishes. Four days after treatment, cells were stained with trypan blue and counted. Error bars indicate SD. The data presented are from three independent experiments.

sensitivity to DOX, MMC, TXL, and TXT, respectively. Treatment of MDA-MB-231 cells with AS Bcl-2 resulted in 5.9-fold, 3.1-fold, 6.5-fold and 5.2-fold increases in sensitivity to DOX, MMC, TXL, and TXT, respectively. These results indicate that downregulation of $\mathrm{Bcl}-2$ by $\mathrm{AS} \mathrm{Bcl}-2$ ODNs in breast cancer cells that normally overexpress $\mathrm{Bcl}-2$ enhances their drug sensitivity, especially the sensitivity to DOX and taxanes.

\section{Sequence-specific downregulation and cytotoxic effects of AS BCl-xL}

We examined the effect of transfection with $1.0 \mu \mathrm{M}$ AS Bcl- $x \mathrm{~L}$, mismatch, and random ODNs, on $\mathrm{Bcl}-\mathrm{xL}$ protein expression in MDA-MB-231 and BT-474 cells (Fig. 3a). A 70\% decrease in $\mathrm{Bcl}-\mathrm{xL}$ protein expression was observed in cells treated with 
Table 2

Effect of antisense Bcl-xL oligodeoxynucleotides on chemosensitivity in BT-474, ZR-75-1, and MDA-MB-231 breast cancer cells

\begin{tabular}{|c|c|c|c|c|c|}
\hline \multirow[t]{2}{*}{ Cell line } & \multirow[t]{2}{*}{ Drug } & \multicolumn{3}{|c|}{$\mathrm{IC}_{50}(\mu \mathrm{M})^{\mathrm{a}}$} & \multirow[t]{2}{*}{ Fold increase in AS Bcl-xL } \\
\hline & & Control & Sense $B c l-x L^{b}$ & AS $B c l-x L^{b}$ & \\
\hline \multirow[t]{5}{*}{ BT-474 } & AS $B c l-x L$ & 4.0 & -- & -- & -- \\
\hline & DOX & 1.0 & 0.92 & 0.68 & 1.5 \\
\hline & $\mathrm{MMC}$ & 1.4 & 1.32 & 0.88 & 1.6 \\
\hline & TXL & 2.4 & 2.2 & 1.34 & 1.8 \\
\hline & TXT & 0.54 & 0.51 & 0.26 & 2.1 \\
\hline \multirow[t]{5}{*}{ ZR-75-1 } & AS $B c /-x L$ & 1.8 & -- & -- & -- \\
\hline & DOX & 0.54 & 0.51 & 0.71 & 1.3 \\
\hline & MMC & 0.84 & 0.79 & 0.39 & 2.2 \\
\hline & TXL & 1.9 & 1.8 & 1.2 & 1.6 \\
\hline & TXT & 3.1 & 3.0 & 1.7 & 1.8 \\
\hline \multirow[t]{5}{*}{ MDA-MB-231 } & AS $B c /-x L$ & 2.2 & -- & -- & -- \\
\hline & DOX & 0.19 & 0.18 & 0.076 & 2.5 \\
\hline & MMC & 0.68 & 0.65 & 0.19 & 3.6 \\
\hline & TXL & 2.8 & 2.6 & 0.96 & 2.9 \\
\hline & TXT & 1.2 & 1.1 & 0.62 & 1.9 \\
\hline
\end{tabular}

AS, antisense; DOX, doxorubicin; $\mathrm{IC}_{50}$, concentration for 50\% inhibition; MMC, mitomycin C; TXL, paclitaxel; TXT, docetaxel.

aThe data are the means of three separate experiments $(\mathrm{SD}<5 \%)$; bells were treated with $1 \mu \mathrm{M}$ sense $B c l-x L$ or antisense $B c l-x L$.

AS Bcl-xL ODNs, compared with control cells, but treatment with mismatch or random ODNs produced little change. These findings indicate that the effects of treatment with AS Bcl- $x \mathrm{~L}$ are due to its specificity for $B c /-x L$ mRNA. The decrease in $\mathrm{Bcl}-\mathrm{xL}$ protein expression by the treatment with $\mathrm{AS} B c /-x L$ was confirmed by quantification by densitometric analysis (Fig. 3b). As shown in Fig. 3c, treatment with AS Bcl- $x L$ ODNs resulted in dose-dependent inhibition of cell proliferation. In contrast, control sense oligonucleotides had minimal effects on cell growth at concentrations up to $2.0 \mu \mathrm{M}$. Greater oligonucleotide concentrations resulted in cytotoxicity. The optimal dose of AS Bcl- $x L$ ODNs was determined as $1.0 \mu \mathrm{M}$ to strike a balance between the dose-response effect and cytotoxicity. In ZR-75-1 cells, the suppression of Bcl-xL protein expression by AS Bcl- $x \mathrm{~L}$ was also about $70 \%$, and the optimal dose of AS $B c l-x L$ was $1.0 \mu \mathrm{M}$, in terms of limiting its cytotoxicity (data not shown).

\section{Effect of AS BCl-xL on chemosensitivity}

We examined the chemosensitivity of MDA-MB-231, BT-474, and ZR-75-1 cells to DOX, MMC, TXL, and TXT in the presence and absence of AS Bcl- $x L$ with the MTT assay. As shown in Table 2, although pretreatment with sense $B c l-x L$ affected the chemosensitivity somewhat, the sensitivity to DOX, MMC,
TXL, and TXT in MDA-MB-231 cells was increased 2.5-fold, 3.6-fold, 2.9-fold, and 1.9-fold, respectively, by pretreatment with $A S B C l-x L$, as determined by increases in $I_{50}$ values. In addition, drug sensitivity to DOX, MMC, TXL, and TXT in BT474 cells was increased 1.5 -fold, 1.6 -fold, 1.8 -fold, and 2.1 fold, respectively, and drug sensitivity to DOX, MMC, TXL, and TXT in ZR-75-1 cells was increased 1.3-fold, 2.2-fold, 1.6-fold, and 1.8-fold, respectively. These results indicate that downregulation of $\mathrm{Bcl}-x \mathrm{~L}$ by $\mathrm{AS} B \mathrm{Cl}-x \mathrm{~L}$ enhances drug sensitivity, but not to the same extent as downregulation of Bcl-2. This is particularly true for DOX and taxanes.

\section{Effect of transfection with the bcl-2 gene on chemosensitivity}

To determine the effect of Bcl-2 on chemosensitivity, cell proliferation was compared between MDA-MB-453/pZip ${ }_{\text {neo }}$ and MDA-MB-453/Bcl-2-1 cells, which were transfected with empty plasmid vector or plasmid vector encoding the $b c /-2$ gene. As shown in Fig. 4, MDA-MB-453 cells were resistant to DOX and MMC after transfection with the bcl-2 gene $(P<$ 0.05 , Student's $t$-test), whereas drug sensitivity to taxanes was not changed. Two other clones transfected with the $\mathrm{bcl}-2$ gene had similar drug sensitivities to those of control cells transfected with vector alone (data not shown). 
Figure 4

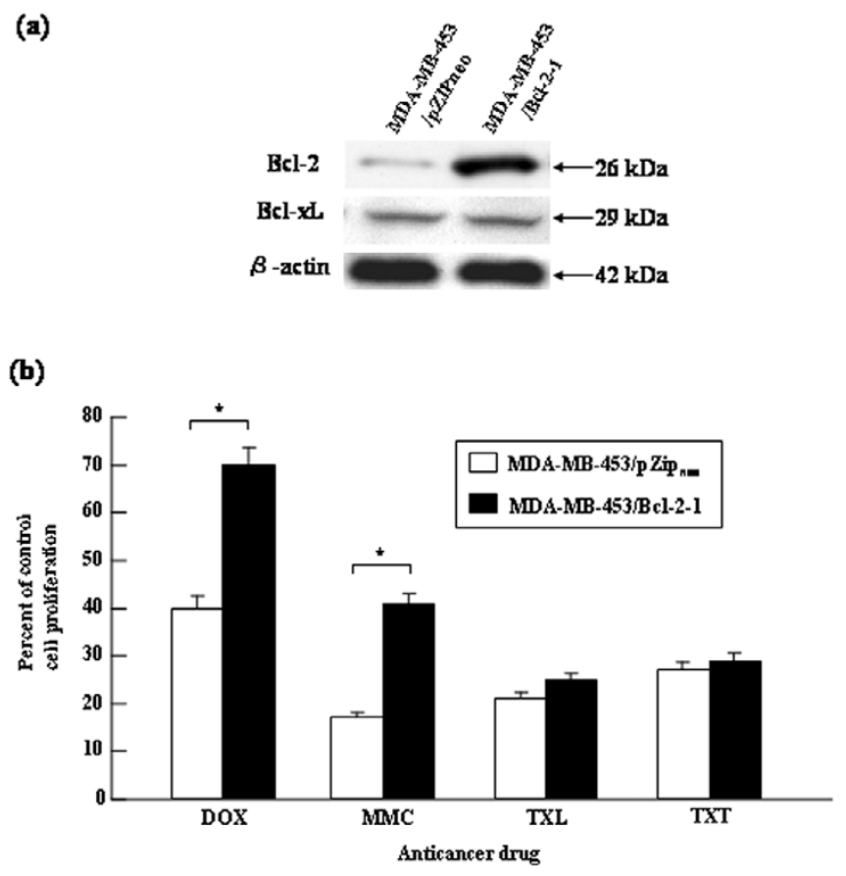

Changes in chemosensitivity of MDA-MB- 453 cells to anticancer drugs after transfection with $b c /-2$ gene. (a) Expression levels of $\mathrm{Bcl}-2$ and $\mathrm{Bcl}-\mathrm{xL}$ were examined in MDA-MB-453 cells by Western blot analysis. MDA-MB-453 cells transfected with the $b c /-2$ gene expressed greater levels of $\mathrm{Bcl}-2$ protein; however, similar levels of $\mathrm{Bcl}-\mathrm{xL}$ protein were observed. (b) Cells treated with $0.15 \mu \mathrm{M}$ doxorubicin (DOX) or with 2.0 $\mu \mathrm{M}$ mitomycin $\mathrm{C}$ (MMC), paclitaxel (TXL) or docetaxel (TXT). After 48 hours, cells were stained with trypan blue and counted. Each point represents the mean of triplicate experiments. Error bars indicate SD. ${ }^{*}, P$ $<0.05$, Student's $t$-test. The data presented are from three independent experiments.

\section{Effect of AS Bcl-2 on expression of apoptosis-related proteins}

To investigate the effect of combined treatment with anticancer drugs and AS BCl-2 on apoptosis, we analyzed the expression of apoptosis-related proteins by Western blotting. As shown in Fig. 5, treatment with AS Bcl-2 and DOX markedly suppressed $\mathrm{Bcl}-2$ expression from that observed after treatment with DOX alone. Combined treatment with AS Bcl-2 and DOX enhanced the expression of Bax, which is a proapoptotic protein, and inhibited phosphorylated Akt (pAkt), which is an antiapoptotic protein. Furthermore, the cleaved PARP increased over time after combined treatment with AS $\mathrm{BCl}-2$ and DOX, indicating an increased rate of apoptotic cell death.

\section{Effect of combined treatment with AS Bcl-2 and various anticancer drugs in vivo}

To investigate the effects of combined treatment with AS Bc/2 and various anticancer agents in vivo, we examined tumor growth after combined treatment of BT-474 and ZR-75-1 cells
Figure 5

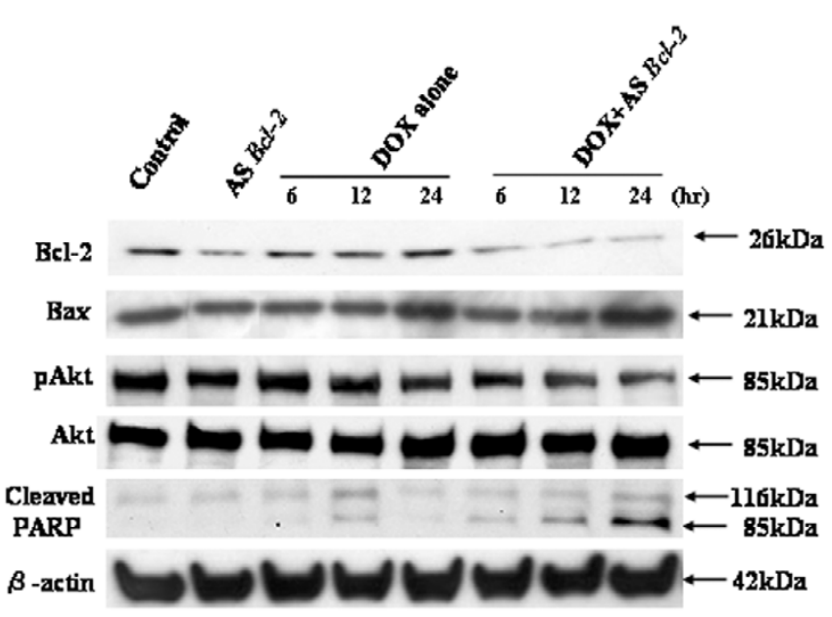

Effect of treatment of ZR-75-1 cells with antisense $\mathrm{Bcl}-2$ and doxorubicin on the apoptosis-related proteins. Cells were pretreated with 10 $\mu \mathrm{g} / \mathrm{ml}$ Lipofectamine alone, or $1.0 \mu \mathrm{M}$ antisense $B c /-2$ oligodeoxynucleotides, for 24 hours. Cells were then cultured in standard medium, after which they were treated with $0.5 \mu \mathrm{M}$ doxorubicin (DOX) for 6,12 , or 24 hours. Whole cell lysate was then extracted and subjected to Western blotting. The data presented are from more than two independent experiments.

transplanted into athymic mice with $\mathrm{AS} B \mathrm{~B}-2$ and MMC, DOX, $T X L$, and TXT. On the basis of the protocols used in previous ODN-treatment studies, mice were treated with $5 \mathrm{mg} / \mathrm{kg}$ AS $B c /-2$ and either $10 \mathrm{mg} / \mathrm{kg}$ TXL or TXT, $6 \mathrm{mg} / \mathrm{kg} \mathrm{DOX,} \mathrm{or} 2$ $\mathrm{mg} / \mathrm{kg} \mathrm{MMC}[7,12,22]$. As shown in Fig. 6a, Bcl-2 expression was suppressed on day 4 , and almost completely inhibited on day 15 , after treatment with AS Bcl-2, which was given by intraperitoneal injection every other week for 4 weeks. In contrast, $\mathrm{Bcl}-\mathrm{xL}$ did not change after treatment with AS Bcl-2.

Treatment of BT-474 cells with DOX, MMC, or TXT alone, inhibited tumor growth, whereas treatment with TXL caused less inhibition of tumor growth compared with control tumor volumes. However, combined treatment with AS Bcl-2 and various anticancer agents caused marked inhibition of tumor growth (Fig. 6b). Statistical analysis showed significant enhancement of the antitumor effect by combinations of AS $B c /-2$ and anticancer drugs in the treatment group $(P<0.05$, ANOVA with Fisher's least significant difference (LSD) test). Similarly, combined treatment of ZR-75-1 cells with anticancer drugs and $A S B C l-2$ also enhanced the antitumor effects of MMC, DOX, TXT, and TXL (Fig. 7). AS Bcl-2 statistically enhanced sensitivities to all of the chemotherapeutic agents $(P<0.05$, ANOVA with Fisher's LSD test). None of the mice treated with AS Bcl-2 and anticancer drugs displayed any signs of toxicity. The toxicity of the combined treatments with AS BCl-2 and various anticancer drugs was assessed by comparing weight loss between treated and untreated mice. The weight loss in treated mice was less than $10 \%$ (data not shown). 


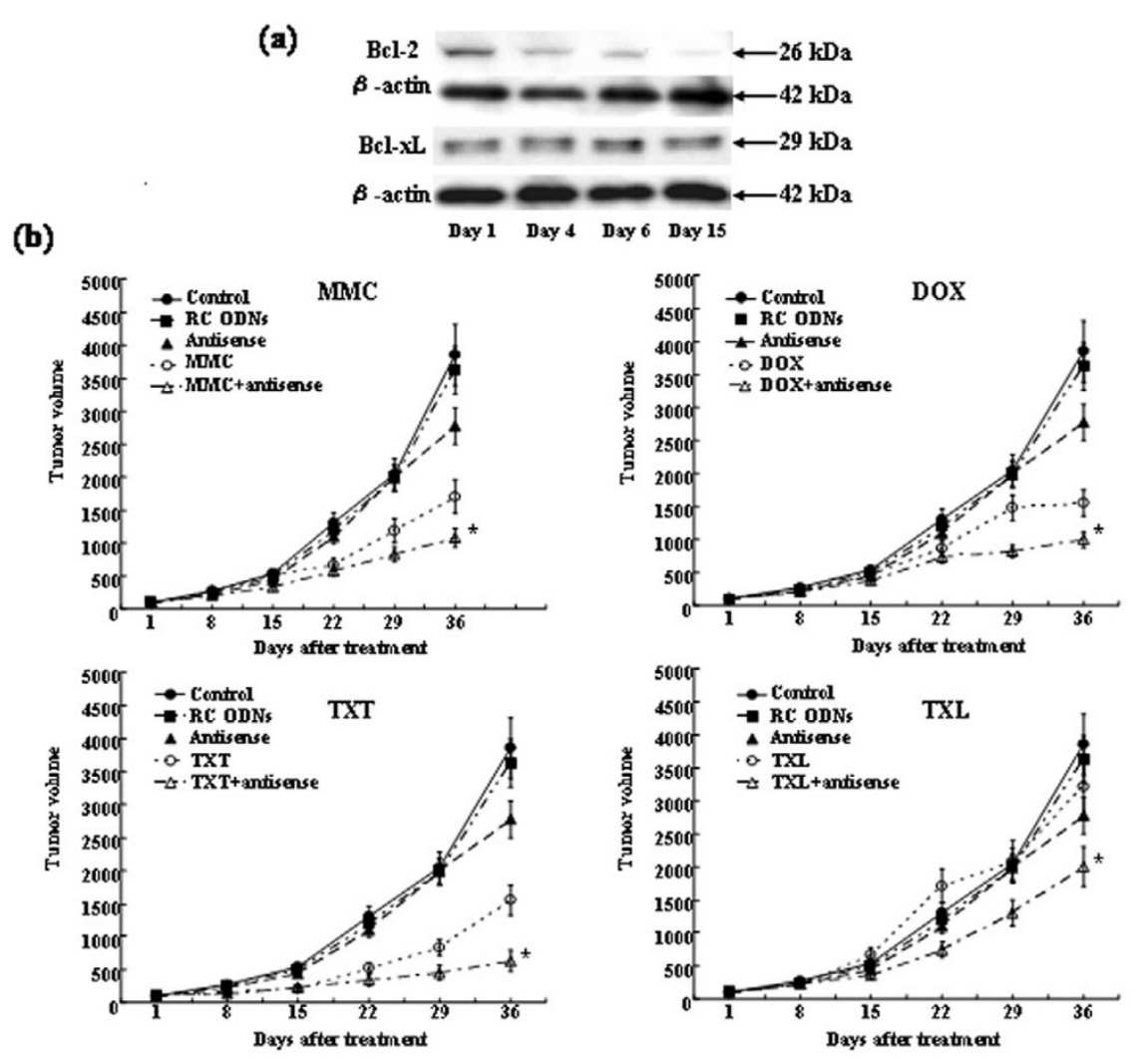

Effects of treatment with antisense $\mathrm{Bcl}-2$ and mitomycin $\mathrm{C}$, doxorubicin, paclitaxel, or docetaxel on BT-474 cells. (a) Expression levels of Bcl-2 and $\mathrm{Bcl}-\mathrm{xL}$ protein in BT-474 cells transplanted into athymic mice after treatment with antisense (AS) Bcl-2 oligodeoxynucleotides (ODNs) were measured by Western blot analysis at the indicated time points. (b) Enhancement of the antitumor effects of anticancer drugs by AS Bcl-2 ODNs in BT474 tumor xenografts. Each point represents the mean tumor volume of the eight mice in each group. Error bars indicate SD. ${ }^{\star}, P<0.05$, analysis of variance with Fisher's least significant difference test. The data presented are from two independent experiments. MMC, mitomycin C; DOX, doxorubicin; TXL, paclitaxel; TXT, docetaxel.

\section{Effects of combined treatment with AS Bcl-xL and various anticancer drugs in vivo}

The effects of combined treatment with $A S B c l-x L$ and various anticancer drugs were investigated with MDA-MB-231 cells transplanted into athymic mice. As shown in Fig. 8a, Bcl-xL expression was decreased on day 4 , further decreased on day 6 , and remained low 15 days after treatment with AS Bcl- $x \mathrm{~L}$. In contrast, Bcl-2 did not change after AS Bcl- $x L$ treatment. Treatment with AS Bcl- $x L$ alone inhibited tumor growth; however, AS Bcl- $x L$ did not enhance the antitumor effects of anticancer agents in MDA-MB-231 cells, apart from MMC (Fig. 8b). Statistical differences in tumor growth were not observed in the combined and regular treatment groups, except for MMC. Combined treatment with AS $B C l-x L$ and MMC significantly enhanced the antitumor effect of $\mathrm{MMC}(P<0.05$, ANOVA with Fisher's LSD test). None of the mice treated with AS BCl- $x \mathrm{~L}$ and anticancer drugs displayed any signs of toxicity. The weight loss in treated mice was less than 10\% (data not shown).

\section{Immunostimulatory and antitumor effects of AS Bcl-2 compared with AS Bcl-2 with methylated CpG motifs}

To evaluate the possible immunostimulatory role of the $\mathrm{CpG}$ motifs of AS Bcl-2, we compared the effects of treatment with AS Bcl-2 with treatment with synthetic CpG AS Bcl-2, in which there is 5'-methylation of the CpG-motif cytosine residues. Mice were treated for 14 days by repeated daily bolus

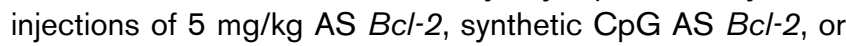
saline control. Mice treated with AS Bcl-2 demonstrated greater IL-12 levels and splenomegaly, compared with the mice treated with saline and with synthetic $\mathrm{CpG}$ AS Bcl-2 (Fig. 9). Differences in IL-6 and IFN- $\gamma$ levels were not observed in mice treated with $\mathrm{AS} B \mathrm{Bl}$-2-treated and with synthetic $\mathrm{CpG}$ AS Bcl-2 (data not shown). The antitumor effect of methylated AS Bcl-2 was evaluated in BT-474 cells, and the results of treatment with TXT and AS Bcl-2 were compared with those of treatment with TXT and synthetic CpG AS Bcl-2. TXT was given intraperitoneally once a week for 4 weeks, and AS Bc/2 was given intraperitoneally 6 days a week, every other week 

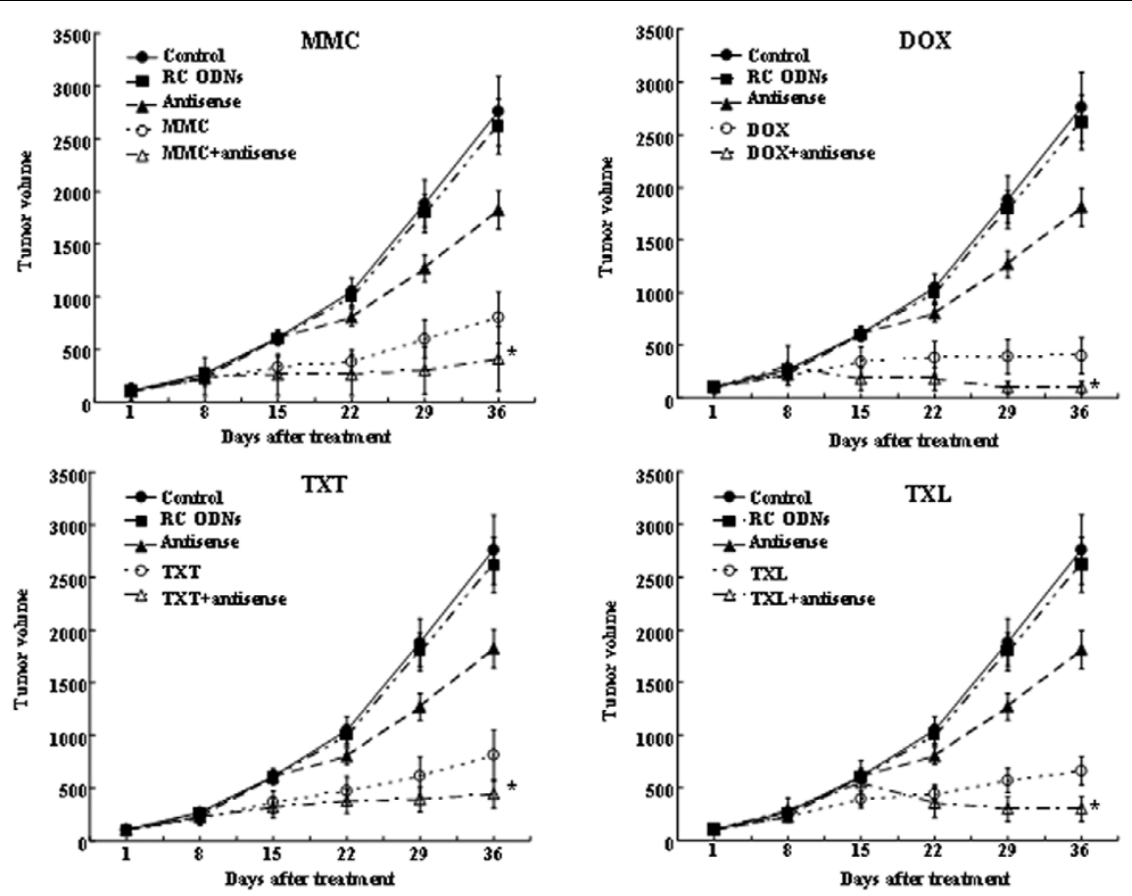

Effects of treatment with antisense $\mathrm{Bcl}-2$ and mitomycin $\mathrm{C}$, doxorubicin, paclitaxel, or docetaxel on ZR-75-1 cells. Enhancement of the antitumor effects of anticancer drugs by antisense Bcl-2 oligodeoxynucleotides in ZR-75-1 tumor xenografts. Each point represents the mean tumor volume of the eight mice in each group. Error bars indicate SD. ${ }^{*}, P<0.05$, analysis of variance with Fisher's least significant difference test. The data presented are from two independent experiments. MMC, mitomycin C; DOX, doxorubicin; TXL, paclitaxel; TXT, docetaxel.

for 4 weeks. As shown in Fig. 10, treatment with TXT and AS $B c l-2$, as well as that with TXT and synthetic CpG AS Bcl-2, resulted in enhanced sensitivity to TXT. In addition, no differences in the antitumor effects of AS Bcl-2 and synthetic CpG AS Bcl-2 were observed.

\section{Discussion}

In the present study we showed that treatment with AS Bcl-2 and $A S B C l-x L$ ODNs produced sequence-specific decreases in protein levels, thereby enhancing the chemosensitivity of BT-474, ZR-75-1, and MDA-MB-231 breast cancer cells to various anticancer drugs both in vitro and in vivo. Treatment with AS Bcl-2 caused greater enhancement of chemosensitivity than treatment with AS Bcl-xL. A number of factors might explain the different effects of $A S B c /-2$ and $A S B c l-x L$ on chemosensitivity, despite the fact that both $\mathrm{Bcl}-2$ and $\mathrm{Bcl}-\mathrm{xL}$ inhibit apoptotic cell death through the mitochondrial pathway. One determining factor might be the differential expression of $\mathrm{Bcl}-2$ and $\mathrm{Bcl}-\mathrm{xL}$ in breast cancer cells. Overexpression of Bcl2 is observed more frequently than overexpression of $\mathrm{Bcl}-\mathrm{xL}$ (70\% versus $40 \%$ ) in breast cancer tissue, which suggests a more important role for $\mathrm{Bcl}-2$ in conferring drug resistance.

Another influencing factor might be a difference in the ability of sequence-specific AS ODNs to suppress Bcl-2 and Bcl-xL expression. Although our results indicate that greater suppression of $\mathrm{Bcl}-2$ than $\mathrm{Bcl}-\mathrm{xL}$ was achieved, the in vitro and in vivo data obtained in this study suggest that differences in Bcl-2 and $\mathrm{Bcl}-\mathrm{xL}$ suppression do not fully explain their differing effects on chemosensitivity. The differential effects of Bcl-2 and $\mathrm{Bcl}-\mathrm{xL}$ on drug sensitivity might be unique to breast cancer. In addition, despite similarities in function in the Bcl-2 family proteins, there is evidence to suggest that $\mathrm{Bcl}-2$ and $\mathrm{Bcl}-\mathrm{xL}$ are subject to different regulatory mechanisms. Bcl-2 inhibits Bid-induced apoptosis at the mitochondrial level by blocking cytochrome $c$ release, whereas $\mathrm{Bcl}-\mathrm{xL}$ does not affect the insertion of tBid into mitochondrial membranes [23,24]. Some reports suggest that $\mathrm{Bcl}-\mathrm{xL}$, but not $\mathrm{Bcl}-2$, is capable of modulating apoptosis induced by tumor necrosis factorrelated apoptosis ligand (TRAIL) [25].

With regard to the effects of AS Bcl-2 on chemosensitivity, sensitivity to DOX and taxanes in vitro was increased to a greater extent than sensitivity to MMC in BT-474, ZR-75-1, and MDA-MB-231 cells. Moreover, enhanced sensitivity to DOX and taxanes was more pronounced in BT- 474 cells than in ZR-75-1 cells. These findings suggest that the downregulation of $\mathrm{Bcl}-2$ expression by $\mathrm{AS} \mathrm{Bc}-2$ enhances drug sensitivity by modulating the apoptotic signal transduction pathway of $\mathrm{Bcl}-2$. The apoptotic signal transduction pathway commonly induced by anticancer agents is associated with the induction of Bax and cleaved PARP, and the downregulation of $\mathrm{Bcl}-2$ and pAkt. Bcl-2 expression is regulated by the ER-responsive element of the promoter region of the bcl-2 gene [26], such 


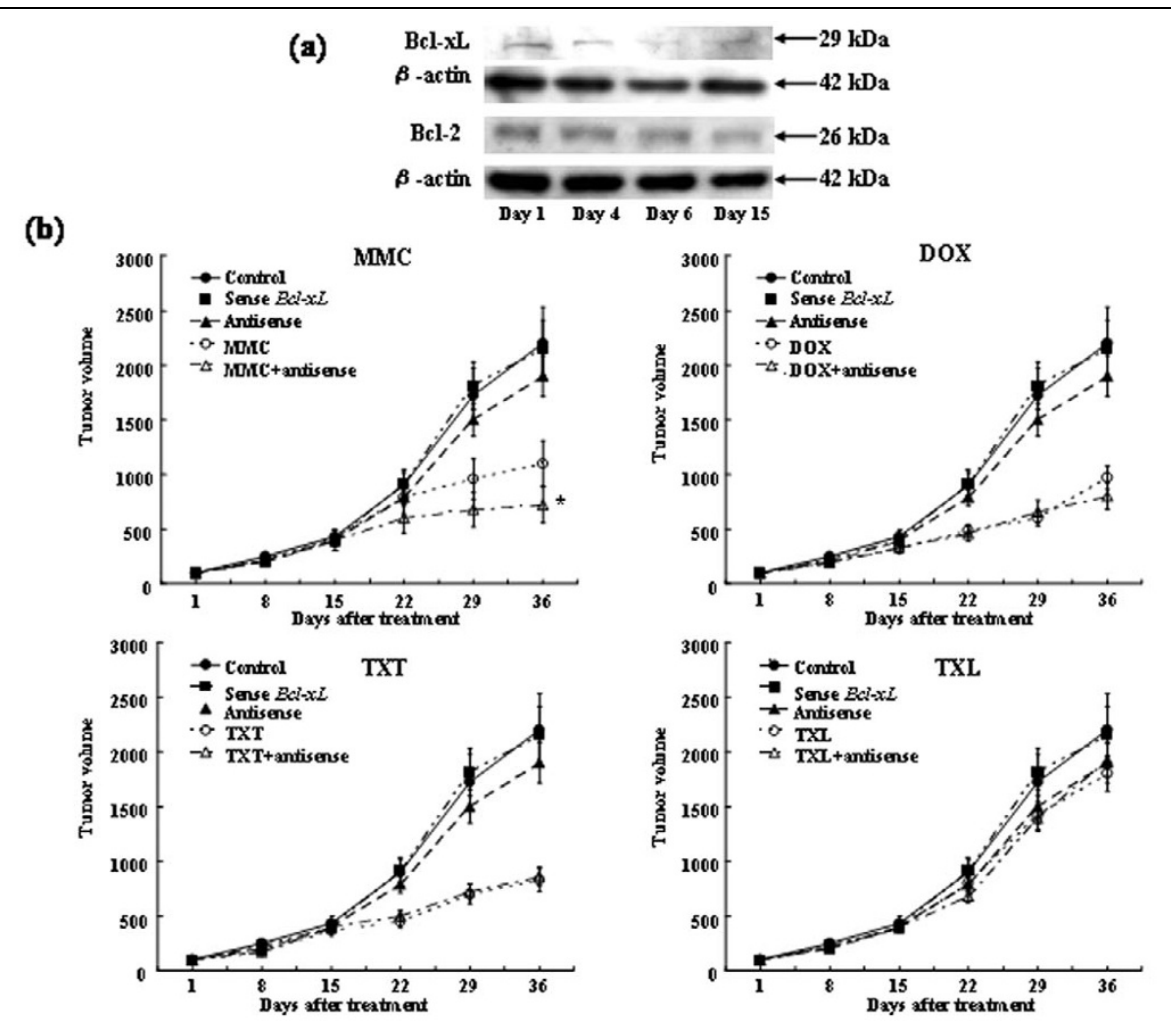

Effects of treatment with antisense $B c /-x L$ and mitomycin $\mathrm{C}$, doxorubicin, paclitaxel, or docetaxel on MDA-MB-231 cells. (a) Expression levels of Bcl$\mathrm{xL}$ and $\mathrm{Bcl}-2$ protein in MDA-MB-231 cells transplanted into athymic mice after treatment with antisense (AS) Bcl- $x \mathrm{~L}$ oligodeoxynucleotides (ODNs) were measured by Western blot analysis at the indicated time points. (b) Enhancement of the antitumor effects of anticancer drugs by AS Bcl-xL ODNs in MDA-MB-231 tumor xenografts. Each point represents the mean tumor volume of the four mice in each group. Error bars indicate SD. ${ }^{*}, P$ $<0.05$, analysis of variance with Fisher's least significant difference test. The data presented are from two independent experiments. MMC, mitomycin C; DOX, doxorubicin; TXL, paclitaxel; TXT, docetaxel.

that overexpression of $\mathrm{Bcl}-2$ might be expected to confer greater drug resistance on ER-positive breast cancer cells. Increases in chemosensitivity to DOX and taxanes in vitro did not correlate well with antitumor activity in vivo, suggesting that other factors might influence the response of athymic mice to chemotherapeutic agents. The converse was observed for combined treatment of MDA-MB-231 cells with AS $B c l-x L$ and MMC, for which far greater efficacy was observed in vivo than in vitro.

The role of $\mathrm{Bcl}-2$ in determining the chemosensitivity of breast cancer cells was tested in MDA-MB-453 cells expressing low levels of Bcl-2. Transfection of the $b c /-2$ gene into MDA-MB453 cells decreased their sensitivity to DOX and MMC but not to taxanes such as TXL and TXT. Several studies indicate that in vitro treatment with taxanes induces phosphorylation and inactivation of the Bcl-2 protein as well as apoptosis [27], which might explain why Bcl-2-transfected cells retained their sensitivity to taxanes in the present experiment. Because the enforced overexpression of $\mathrm{Bcl}-2$ can act as an antioxidant in response to DNA damage, the decreased chemosensitivity of the Bcl-2-transfected breast cancer cells to DNA-damaging agents, including DOX and MMC, may be explained by this effect.

Akt is another antiapoptotic protein that belongs to the serine/ threonine kinase family. Bcl-2 is activated by Akt through a cyclic-AMP-responsive element-binding protein (CREB) [28]. An Akt- and Bcl-2-dependent pathway might mediate the prevention of anticancer drug-induced cell death through CREB and NF- $\mathrm{KB}$. Because downregulation of $\mathrm{Bcl}-2$ by $\mathrm{AS} B \mathrm{cl}-2$ might result in downregulation of $\mathrm{pAkt}$, downregulation of $\mathrm{pAkt}$ after treatment with DOX might be augmented by concurrent treatment of ZR-75-1 cells with AS Bcl-2.

Previous reports have suggested that AS ODNs have immunostimulatory effects due to their CpG motifs, in addition to their AS activity [29]. In the present study we observed immune stimulation by $\mathrm{CpG}$ motifs, resulting in significant spleen enlargement and elevated serum IL-12 levels. However, the role of immune stimulation in mediating antitumor activity remains uncertain because AS Bcl-2 ODNs with methylated $\mathrm{CpG}$ motifs, when transplanted into athymic mice, demonstrated antitumor activities that were similar to those of 
(a)

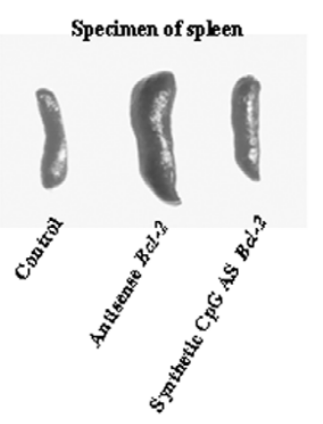

(b)

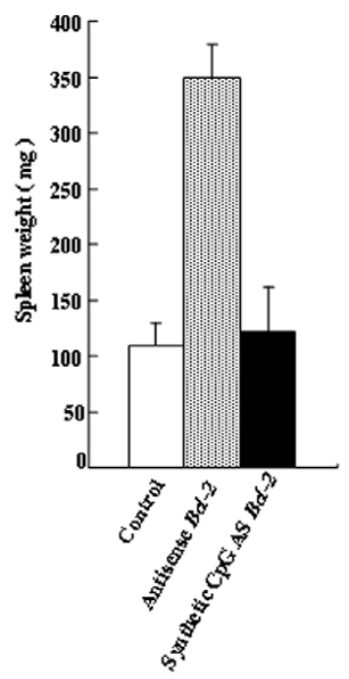

(c)

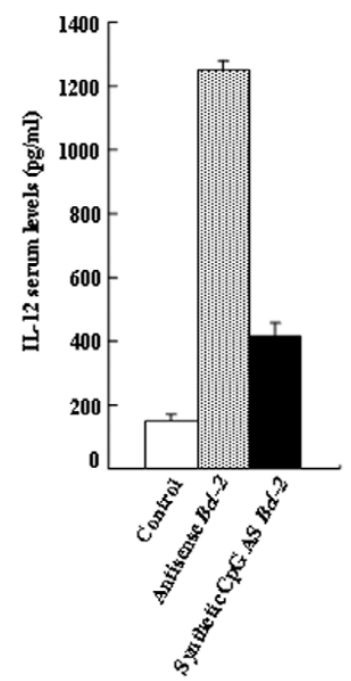

Effect of antisense Bcl-2 oligodeoxynucleotides on splenomegaly development and serum IL-12 levels in athymic mice. (a) Segment of spleen from a mouse with splenomegaly after treatment with antisense (AS) Bcl-2 oligodeoxynucleotides (ODNs), and segments from untreated (control) and synthetic CpG AS Bcl-2 ODN-treated mice. (b) Comparison of splenic weight among mice treated with AS Bcl-2 ODNs, synthetic CpG AS Bcl-2 ODNs, and control mice. (c) Increased serum levels of IL-12 were observed in mice treated with AS Bcl-2 ODNs, compared with those treated with synthetic CpG AS Bcl-2 ODNs, and with control mice. Each point represents the mean of the three mice in each group. Error bars indicate SD. The data presented are from three independent experiments.

\section{Figure 10}

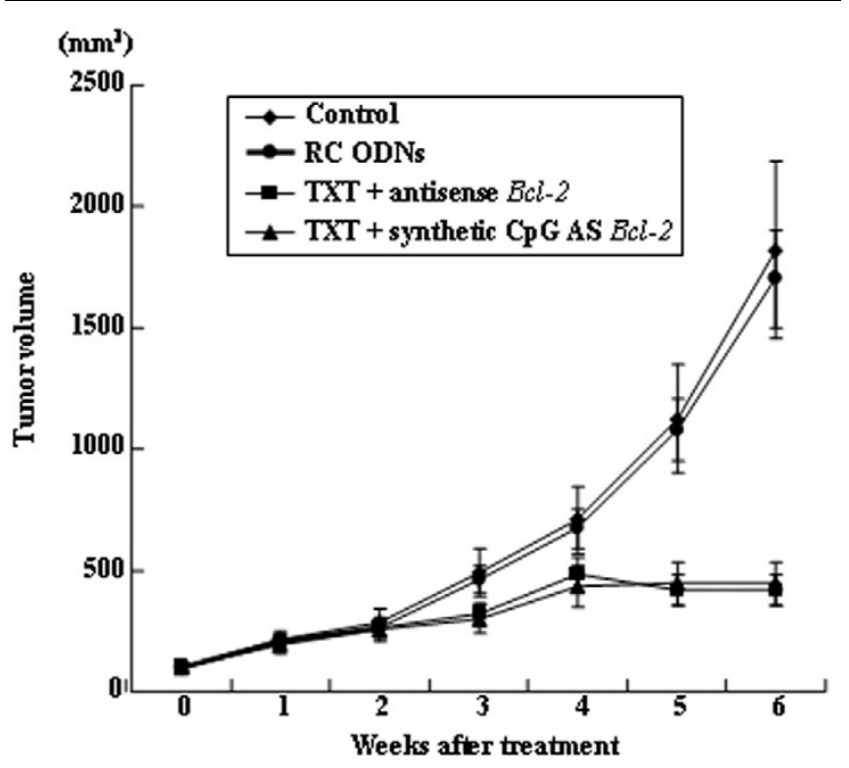

Effect of synthetic $\mathrm{CpG}$ antisense Bcl-2 on BT-474 cells in comparison with antisense $\mathrm{Bcl}-2$. Each point represents the mean tumor volume of the four mice in each group. Error bars indicate SD. The data presented are from two independent experiments. RC, random control; TXT, docetaxel. their nonmethylated counterparts with immunostimulatory activity. We therefore suggest that the therapeutic activity of AS Bcl-2 is due to the AS-mRNA interaction and not to immunostimulatory effects in this model. Similarly, methylated AS Bcl-2, with 5'-methylation of CpG motif cytosine residues, had the same antitumor effect as unmethylated AS Bcl-2 ODNs in human melanoma xenografts transplanted into mice with severe combined immunodeficiency [30]. However, given that AS Bcl-2 stimulates IL-12 secretion and results in the development of splenomegaly, effects that are not observed with methylated AS Bcl-2, Th1-mediated immunostimulation may have antitumor effects in solid tumors in humans. Further studies are required to determine whether the immunostimulatory effects of the CpG motifs in AS Bcl-2 have antitumor effects in the clinical setting.

Phase III clinical trials using Genasense (known as G3139) in the treatment of patients with chronic lymphocyctic leukemia, malignant melanoma, and multiple myeloma are complete, and are nearly complete for non-small cell lung cancer [31]. Although a phase III trial of G3139/dacarbazine versus dacarbazine alone in advanced malignant melanoma does not show a significant increase in overall survival by the addition of G3139, combination treatment with G3139 and dacarbazine shows a significant increase in progression-free survival and response rate, compared with dacarbazine alone [32]. The results of other phase III trials are eagerly anticipated. In addition, phase I and II trials of G3139 in advanced esophageal, 
gastric, and colon cancer are ongoing, as are trials in hepatocellular carcinoma, metastatic breast cancer, and hormone refractory prostate cancer.

\section{Conclusion}

Although AS therapy targeting $\mathrm{Bcl}-2$ and $\mathrm{Bcl}-\mathrm{xL}$ enhances chemosensitivity in breast cancer cells, the effect of blocking $\mathrm{Bcl}-2$ seems superior to that of $\mathrm{Bcl}-\mathrm{xL}$. Downregulation of $\mathrm{Bcl}-$ 2 is associated with enhancement of chemosensitivity to agents such as DOX and taxanes. AS Bcl-2-mediated downregulation of $\mathrm{Bcl}-2$ augments anticancer drug-induced signal transduction pathways leading to apoptosis, which is associated with the activation of proapoptotic proteins such as Bax and the suppression of antiapoptotic proteins such as $\mathrm{Bcl}-2$ and pAkt. Although AS Bcl-2 ODNs induced splenomegaly and increased serum IL-12 levels in the present experiment, suggesting an immunostimulatory effect of AS Bcl-2, the antitumor effect of AS Bcl-2 ODNs seemed to result from downregulation of $\mathrm{Bcl}-2$, independently of $\mathrm{CpG}$-mediated immune stimulation.

\section{Competing interests}

The authors declare that they have no competing interests.

\section{Authors' contributions}

ME carried out the study design, animal feeding, data collection (Western blotting, drug sensitivity assay in vitro and in vivo, transfection, ELISA), statistical analysis, data interpretation, manuscript preparation, and literature search. RK participated in the design and coordination of the study, in the data interpretation, and manuscript preparation. KT and YU participated in the data collection (Western blotting, transfection). TT organized the study as the director, manuscript preparation, and funding the collection. All authors read and approved the final manuscript.

\section{Acknowledgements}

We thank Dr Stanley J Korsmeyer, Dana-Farber Cancer Institute, Harvard Medical School, Boston, for bcl-2 cDNA.

\section{References}

1. Huang Z: Bcl-2 family proteins as targets for anticancer drug design. Oncogene 2000, 19:6627-6631.

2. Kim R, Tanabe K, Uchida Y, Emi M, Inoue H, Toge T: Current status of the molecular mechanisms of anticancer drug-induced apoptosis. The contribution of molecular-level analysis to cancer chemotherapy. Cancer Chemother Pharmacol 2002, 50:343-352.

3. Burlacu A: Regulation of apoptosis by $\mathrm{Bcl}-2$ family proteins. $J$ Cell Mol Med 2003, 7:249-257.

4. Verrier F, Deniaud A, Lebras M, Metivier D, Kroemer G, Mignotte $B$, Jan G, Brenner C: Dynamic evolution of the adenine nucleotide translocase interactome during chemotherapy-induced apoptosis. Oncogene 2004, 23:8049-8064.

5. Krajewski S, Krajewska M, Shabaik A, Wang HG, Irie S, Fong L, Reed JC: Immunohistochemical analysis of in vivo patterns of Bcl-X expression. Cancer Res 1994, 54:5501-5507.

6. Hanada M, Aime-Sempe C, Sato T, Reed JC: Structure-function analysis of $\mathrm{Bcl}-2$ protein. Identification of conserved domains important for homodimerization with $\mathrm{Bcl}-2$ and heterodimerization with Bax. J Biol Chem 1995, 270:11962-11969.
7. Olopade OI, Adeyanju MO, Safa AR, Hagos F, Mick R, Thompson $\mathrm{CB}$, Recant WM: Overexpression of $\mathrm{BCL}-\mathrm{x}$ protein in primary breast cancer is associated with high tumor grade and nodal metastases. Cancer J Sci Am 1997, 3:230-237.

8. Dean NM, Bennett CF: Antisense oligonucleotide-based therapeutics for cancer. Oncogene 2003, 22:9087-9096.

9. Reed JC: $\mathrm{Bcl}-2$ and the regulation of programmed cell death. $J$ Cell Biol 1994, 124:1-6.

10. Chao DT, Korsmeyer SJ: BCL-2 family: regulators of cell death. Annu Rev Immunol 1998, 16:395-419.

11. Zangemeister-Wittke U, Schenker T, Luedke GH, Stahel RA: Synergistic cytotoxicity of bcl-2 antisense oligodeoxynucleotides and etoposide, doxorubicin and cisplatin on small-cell lung cancer cell lines. Br J Cancer 1998, 78:1035-1042.

12. Gleave ME, Miayake H, Goldie J, Nelson C, Tolcher A: Targeting bcl-2 gene to delay androgen-independent progression and enhance chemosensitivity in prostate cancer using antisense bcl-2 oligodeoxynucleotides. Urology 1999, 54:36-46.

13. Chi KC, Wallis AE, Lee CH, De Menezes DL, Sartor J, Dragowska $\mathrm{WH}$, Mayer LD: Effects of Bcl-2 modulation with G3139 antisense oligonucleotide on human breast cancer cells are independent of inherent $\mathrm{Bcl}-2$ protein expression. Breast Cancer Res Treat 2000, 63:199-212.

14. Kim R, Emi M, Tanabe K, Toge T: Preclinical evaluation of antisense bcl-2 as a chemosensitizer for patients with gastric carcinoma. Cancer 2004, 101:2177-2186.

15. Simoes-Wust AP, Olie RA, Gautschi O, Leech SH, Haner R, Hall J, Fabbro D, Stahel RA, Zangemeister-Wittke U: Bcl-xl antisense treatment induces apoptosis in breast carcinoma cells. Int $J$ Cancer 2000, 87:582-590.

16. Xu Z, Friess H, Solioz M, Aebi S, Korc M, Kleeff J, Buchler MW: $\mathrm{Bcl}-\mathrm{xL}$ antisense oligonucleotides induce apoptosis and increase sensitivity of pancreatic cancer cells to gemcitabine. Int J Cancer 2001, 94:268-274.

17. Krieg AM, Hartmann G, Yi AK: Mechanism of action of CpG DNA. Curr Top Microbiol Immunol 2000, 247:1-21.

18. Carpentier AF, Chen L, Maltonti F, Delattre JY: Oligodeoxynucleotides containing CpG motifs can induce rejection of a neuroblastoma in mice. Cancer Res 1999, 59:5429-5432.

19. Ballas ZK, Krieg AM, Warren T, Rasmussen W, Davis HL, Waldschmidt M, Weiner GJ: Divergent therapeutic and immunologic effects of oligodeoxynucleotides with distinct CpG motifs. Immunol 2001, 167:4878-4886.

20. Webb A, Cunningham D, Cotter F, Clarke PA, di Stefano F, Ross $P$, Corbo $M$, Dziewanowska Z: BCL-2 antisense therapy in patients with non-Hodgkin lymphoma. Lancet 1997, 349:1137-1141.

21. Seto M, Jaeger U, Hockett RD, Graninger W, Bennett S, Goldman $\mathrm{P}$, Korsmeyer SJ: Alternative promoters and exons, somatic mutation and deregulation of the Bcl-2-lg fusion gene in lymphoma. EMBO J 1988, 7:123-131.

22. Wang H, Nan L, Yu D, Agrawal S, Zhang R: Antisense anti-MDM2 oligonucleotides as a novel therapeutic approach to human breast cancer: in vitro and in vivo activities and mechanisms. Clin Cancer Res 2001, 7:3613-3624.

23. Yi X, Yin XM, Dong Z: Inhibition of Bid-induced apoptosis by $\mathrm{Bcl}-2$. tBid insertion, Bax translocation, and Bax/Bak oligomerization suppressed. J Biol Chem 2003, 278:16992-16999.

24. Kaufmann T, Schlipf S, Sanz J, Neubert K, Stein R, Borner C: Characterization of the signal that directs $\mathrm{Bcl}-\mathrm{x}(\mathrm{L})$, but not $\mathrm{Bcl}-$ 2 , to the mitochondrial outer membrane. J Cell Biol 2003, 160:53-64.

25. Kim IK, Jung YK, Noh DY, Song YS, Choi CH, Oh BH, Masuda ES, Jung YK: Functional screening of genes suppressing TRAILinduced apoptosis: distinct inhibitory activities of $\mathrm{Bcl}-\mathrm{XL}$ and Bcl-2. Br J Cancer 2003, 88:910-917.

26. Dong L, Wang W, Wang F, Stoner M, Reed JC, Harigai M, Samudio I, Kladde MP, Vyhlidal C, Safe S: Mechanisms of transcriptional activation of bcl-2 gene expression by 17 beta-estradiol in breast cancer cells. J Biol Chem 1999, 274:32099-32107.

27. Haldar S, Basu A, Croce CM: Bcl-2 is the guardian of microtubule integrity. Cancer Res 1997, 57:229-233.

28. Pugazhenthi S, Nesterova A, Sable C, Heidenreich KA, Boxer LM, Heasley LE, Reusch JE: Akt/protein kinase B up-regulates Bcl2 expression through cAMP-response element-binding protein. J Biol Chem 2000, 275:10761-10766. 
29. Weiner GJ, Liu HM, Wooldridge JE, Dahle CE, Krieg AM: Immunostimulatory oligodeoxynucleotides containing the $\mathrm{CpG}$ motif are effective as immune adjuvants in tumor antigen immunization. Proc Natl Acad Sci USA 1997, 94:10833-10837.

30. Wacheck V, Krepler C, Strommer S, Heere-Ress E, Klem R, Pehamberger $\mathrm{H}$, Eichler HG, Jansen B: Antitumor effect of G3139 Bcl-2 antisense oligonucleotide is independent of its immune stimulation by $\mathrm{CpG}$ motifs in SCID mice. Antisense Nucleic Acid Drug Dev 2002, 12:359-367.

31. Kim R, Emi M, Tanabe K, Toge T: Therapeutic potential of antisense $\mathrm{Bcl}-2$ as a chemosensitizer for cancer therapy. Cancer 2004, 101:2491-2502.

32. Millward MJ, Bedikian AY, Conry RM, Gore ME, Pehamberger HE, Sterry W, Pavlick AC, De Conti RC, Gordon D, Itri LM: Randomized multinational phase 3 trial of dacarbazine (DTIC) with or without $\mathrm{Bcl}-2$ antisense (oblimersen sodium) in patients (pts) with advanced malignant melanoma (MM): analysis of long-term survival. Proc Am Soc Clin Oncol 2004, 711:7505. 